Prepared in cooperation with the

U.S. Department of Homeland Security Federal Emergency Management Agency

\title{
Annual Exceedance Probabilities of the Peak Discharges of 2011 at Streamgages in Vermont and Selected Streamgages in New Hampshire, Western Massachusetts, and Northeastern New York
}

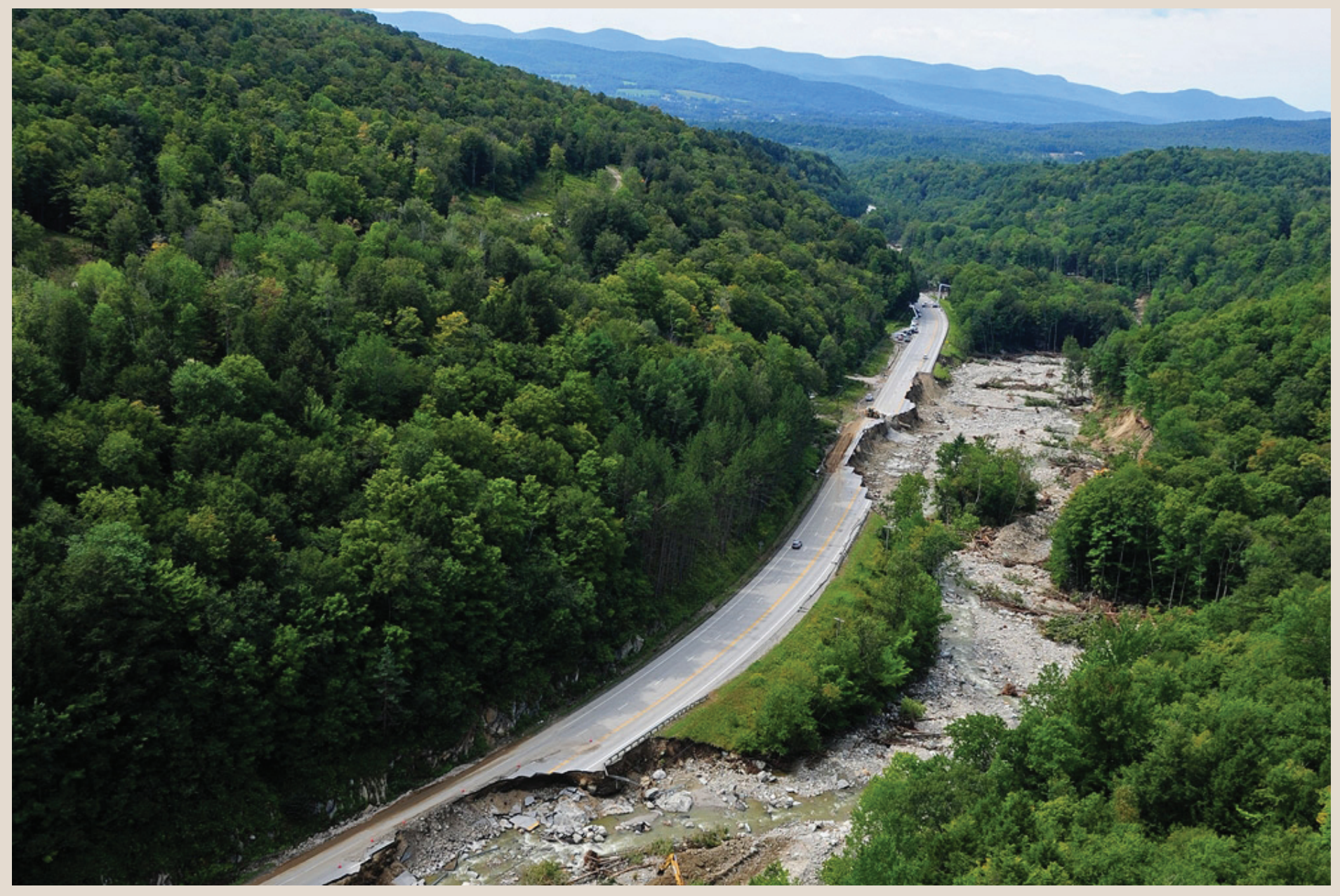

Scientific Investigations Report 2013-5187 
Cover. Aerial view of damage along U.S. Route 4 in Mendon, Vermont, as a result of floodwaters from Mendon Brook during Tropical Storm Irene in August 2011. 


\section{Annual Exceedance Probabilities of the Peak Discharges of 2011 at Streamgages in Vermont and Selected Streamgages in New Hampshire, Western Massachusetts, and Northeastern New York}

By Scott A. Olson and Gardner C. Bent

Prepared in cooperation with the

U.S. Department of Homeland Security Federal Emergency Management Agency

Scientific Investigations Report 2013-5187 


\title{
U.S. Department of the Interior SALLY JEWELL, Secretary
}

\section{U.S. Geological Survey Suzette M. Kimball, Acting Director}

\author{
U.S. Geological Survey, Reston, Virginia: 2013
}

For more information on the USGS - the Federal source for science about the Earth, its natural and living resources, natural hazards, and the environment, visit http://www.usgs.gov or call 1-888-ASK-USGS.

For an overview of USGS information products, including maps, imagery, and publications, visit http://www.usgs.gov/pubprod

To order this and other USGS information products, visit http://store.usgs.gov

Any use of trade, firm, or product names is for descriptive purposes only and does not imply endorsement by the U.S. Government.

Although this information product, for the most part, is in the public domain, it also may contain copyrighted materials as noted in the text. Permission to reproduce copyrighted items must be secured from the copyright owner.

Suggested citation:

Olson, S.A., and Bent, G.C., 2013, Annual exceedance probabilities of the peak discharges of 2011 at streamgages in Vermont and selected streamgages in New Hampshire, western Massachusetts, and northeastern New York: U.S. Geological Survey Scientific Investigations Report 2013-5187, 17 p., http://dx.doi.org/10.3133/sir20135187. 


\section{Contents}

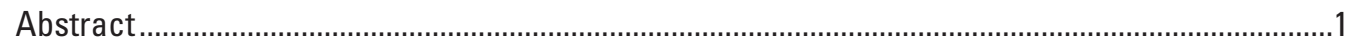

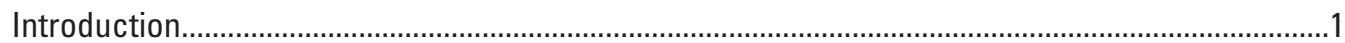

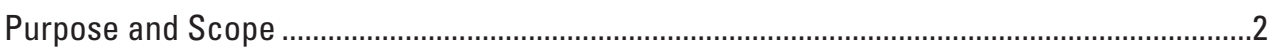

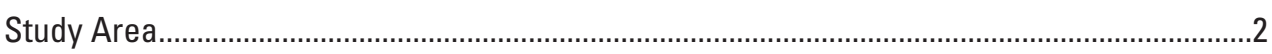

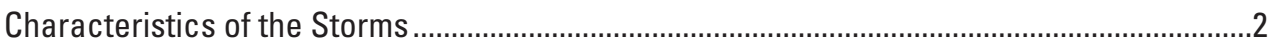

Peak Discharge and Lake Elevation Data for Water Year 2011..................................................2

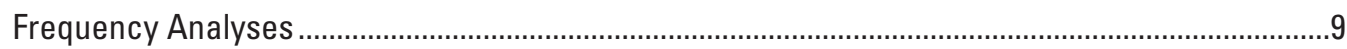

Lake Champlain Peak Elevations and Frequency Analyses ..........................................................

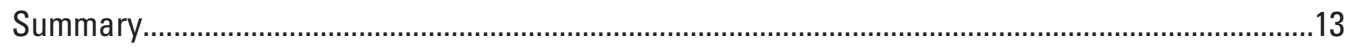

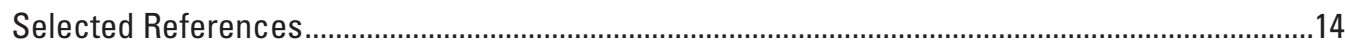

Appendix 1. Location Descriptions of Streamgages and Lake Gages Used to Characterize 2011 Flooding in Vermont, Northern New Hampshire, Western Massachusetts, and Northeastern New York .............................................................................................17

Appendix 2. Peak Discharge or Stage Occurring in 2011 at Streamgages or Lake Gages Used to Characterize 2011 Flooding in Vermont, Northern New Hampshire, Western Massachusetts, and Northeastern New York ...................................................................17

Appendix 3. Discharges for Selected Annual Exceedance Probabilities at Streamgages Used to Characterize Flooding in 2011 in Vermont, Northern New Hampshire, Western Massachusetts, and Northeastern New York.

\section{Figures}

1. Maps showing location of streamgages and lake gages that have data for the 2011 water year, in $A$, northwest section, $B$, northeast section, $C$, western section, $D$, eastern section, and $E$, southern section of Vermont, and $F$, western Massachusetts section

2. Maps showing annual exceedance probabilities less than or equal to 2 percent at streamgages with annual peak discharges during the $A$, April 2011 rain event or Lake Champlain flooding; B, May 2011 rain event; and C, August 2011 Tropical Storm Irene.

\section{Tables}

1. Elevations of Lake Champlain, Vermont and New York, for selected annual exceedance probabilities 


\section{Conversion Factors and Datum}

Inch/Pound to SI

\begin{tabular}{lcl}
\hline & Multiply & \multicolumn{1}{c}{ By obtain } \\
\hline inch (in.) & Length & \\
inch (in.) & 2.54 & centimeter $(\mathrm{cm})$ \\
foot (ft) & 25.4 & millimeter $(\mathrm{mm})$ \\
mile (mi) & 0.3048 & meter $(\mathrm{m})$ \\
\hline & 1.609 & kilometer $(\mathrm{km})$ \\
\hline square mile $\left(\mathrm{mi}^{2}\right)$ & Area & \\
square mile $\left(\mathrm{mi}^{2}\right)$ & 259.0 & hectare $($ ha) \\
\hline & 2.590 & square kilometer $\left(\mathrm{km}^{2}\right)$ \\
\hline cubic foot $\left(\mathrm{ft}^{3}\right)$ & Volume & \\
cubic foot $\left(\mathrm{ft}^{3}\right)$ & 28.32 & cubic decimeter $\left(\mathrm{dm}^{3}\right)$ \\
\hline & 0.02832 & cubic meter $\left(\mathrm{m}^{3}\right)$ \\
\hline cubic foot per second $\left(\mathrm{ft}^{3} / \mathrm{s}\right)$ & Flow rate & \\
cubic foot per second per square mile & 0.02832 & cubic meter per second $\left(\mathrm{m}^{3} / \mathrm{s}\right)$ \\
{$\left[\left(\mathrm{ft}^{3} / \mathrm{s}\right) / \mathrm{mi}^{2}\right]$} & 0.01093 & cubic meter per second per square \\
\hline
\end{tabular}

Temperature in degrees Celsius $\left({ }^{\circ} \mathrm{C}\right)$ may be converted to degrees Fahrenheit $\left({ }^{\circ} \mathrm{F}\right)$ as follows:

${ }^{\circ} \mathrm{F}=\left(1.8 x^{\circ} \mathrm{C}\right)+32$

Temperature in degrees Fahrenheit $\left({ }^{\circ} \mathrm{F}\right)$ may be converted to degrees Celsius $\left({ }^{\circ} \mathrm{C}\right)$ as follows:

${ }^{\circ} \mathrm{C}=\left({ }^{\circ} \mathrm{F}-32\right) / 1.8$

Vertical coordinate information is referenced to the North American Vertical Datum of 1988 (NAVD 88).

Horizontal coordinate information is referenced to the North American Datum of 1983 (NAD 83).

Elevation, as used in this report, refers to distance above the vertical datum. 


\title{
Annual Exceedance Probabilities of the Peak Discharges of 2011 at Streamgages in Vermont and Selected Streamgages in New Hampshire, Western Massachusetts, and Northeastern New York
}

\author{
By Scott A. Olson and Gardner C. Bent
}

\begin{abstract}
The U.S. Geological Survey, in cooperation with the Federal Emergency Management Agency, determined annual exceedance probabilities for peak discharges occurring during the 2011 water year (October 1 to September 30) at streamgages in Vermont and selected streamgages in New Hampshire, western Massachusetts, and northeastern New York. This report presents the 2011 water year peak discharges at 145 streamgages in the study area and provides the results of the analyses of the 50-, 20-, 10-, 4-, 2-, 1-, and 0.2-percent annual exceedance probability discharges at 135 of the 145 streamgages. The annual exceedance probabilities for the 2011 water year peak discharges also are presented.

Snowmelt and near record rainfall led to flooding across northern Vermont on April 27 and 28, 2011. At three streamgages with more than 10 years of record, the April rain event resulted in the peak discharge of record. At seven streamgages, the peak discharge resulting from this event had an annual exceedance probability less than or equal to 1 percent. In early May 2011, new peak stage records were set at two Lake Champlain gages with more than 100 years of record. At the Lake Champlain at Burlington, Vermont, gage, the water surface reached 102.79 feet (ft) (North American Vertical Datum of 1988 (NAVD 88)) on May 6, 2011, and at the Richelieu River (Lake Champlain) at Rouses Point, New York, gage, the water surface reached $102.75 \mathrm{ft}$ NAVD 88 .

Record-breaking rainfall in late May produced additional flooding across northern Vermont on May 26 and 27, 2011. Four streamgages in northwestern Vermont recorded peak-of-record discharges as a result of this flooding. At three streamgages, the peak discharges from this event had an annual exceedance probability less than or equal to 1 percent.

From August 28 to 29, 2011, Tropical Storm Irene delivered rainfall totals ranging from about 3 to more than 10 inches, which resulted in extensive flooding and new period-of-record peak discharges at 37 streamgages in the study area. The peak discharges as a result of Tropical
\end{abstract}

Storm Irene had an annual exceedance probability of less than or equal to 1 percent at 36 streamgages. At 11 of these 36 streamgages, the annual exceedance probability of the peak discharges was less than or equal to 0.2 percent.

\section{Introduction}

Record-breaking rainfall during the spring of 2011 resulted in riverine flooding across northern Vermont and historic flooding of Lake Champlain, causing substantial damage to public and personal property. In late August 2011, more record-breaking rainfall from Tropical Storm Irene resulted in extensive destruction across much of Vermont, western Massachusetts, northern New Hampshire, and parts of eastern New York. Of the 120 streamgages and lake gages in the study area (appendix 1) with more than 10 years of record as of 2011, 47 had a new period-of-record peak discharge during water year ${ }^{1} 2011$. Peaks of record were recorded at 3 streamgages in April, 3 lake gages and 4 streamgages in May, and 37 streamgages during the August flooding.

Presidential declarations (Federal Emergency Management Agency [FEMA]-1995-DR, FEMA-4001-DR, FEMA-4006-DR, and FEMA-4043-DR) of major disasters were made in June, July, and November 2011 under the Robert T. Stafford Disaster Relief and Emergency Assistance Act (Stafford Act) ${ }^{2}$ as the result of the severe storms and flooding during April and May 2011 in New Hampshire and Vermont. Following Tropical Storm Irene, President Obama declared four additional major disasters- FEMA-4020-DR, FEMA-4022-DR, FEMA-4026-DR, and FEMA-4028-DR - on September 1, 2011, for the States of New York, Vermont, New Hampshire, and Massachusetts, respectively.

${ }^{1} \mathrm{~A}$ water year is the 12 -month period beginning October 1 and ending September 30. It is designated by the year in which it ends.

${ }^{2}$ Robert T. Stafford Disaster Relief and Emergency Assistance Act, Pub. L. No. 93-288 (1974) (codified as amended at 42 U.S.C. $\S \S 5121-5207$ ). 
In response to these declarations, the U.S. Geological Survey (USGS), in cooperation with the Federal Emergency Management Agency (FEMA), conducted a study to document the 2011 water year peak discharge or lake stage at 145 gages and determine the annual exceedance probability of those peaks.

\section{Purpose and Scope}

This report presents peak discharges and stages occurring during the 2011 water year at streamgages and lake gages in Vermont (94 gages), western Massachusetts (20 gages), northern New Hampshire (19 gages), and parts of eastern New York (12 gages). The annual exceedance probabilities of the peak discharges or stages are also presented.

\section{Study Area}

All USGS streamgages in Vermont with recorded data are included in this report. Streamgages in Massachusetts, New Hampshire, and New York that are within or adjacent to areas where disasters were declared as a result of significant flooding also are included. These areas encompass much of western Massachusetts, western and northern New Hampshire, and eastern New York immediately adjacent to Vermont and Massachusetts.

The study area is largely forested with rolling hills and the more mountainous terrain of the Appalachian Mountains running through much of the center of the area. Land-surface elevations range from approximately 40 feet (ft) along the Connecticut River at the southernmost end of the study area and $100 \mathrm{ft}$ along the shoreline of Lake Champlain to numerous peaks higher than $3,000 \mathrm{ft}$. The climate of the region is humid, and precipitation is distributed fairly evenly across the region with averages ranging from about 40 to 50 inches (in.) per year, except in regions of high elevation which can receive an additional 10 to $20 \mathrm{in}$. of precipitation annually. The annual mean temperature is 46 degrees Fahrenheit $\left({ }^{\circ} \mathrm{F}\right)$ at Burlington, Vt., $44.6^{\circ} \mathrm{F}$ in Rutland, Vt., and $45.3^{\circ} \mathrm{F}$ in Pittsfield, Mass. The number of days per year the minimum temperature is less than or equal to $32^{\circ} \mathrm{F}$ is, on average, 144 in Burlington, Vt., 169 in Rutland, Vt., and 157 in Pittsfield, Mass. (National Weather Service, 2012 and 2013).

\section{Characteristics of the Storms}

During April 2011, frequent rain events resulted in the monthly total rainfall of 3 to 5 in. above average. The largest rainfall totals that month occurred on April 26 and 27. This rain along with snowmelt resulted in flooding across northern Vermont on April 27 and 28. Frequent rains continued through May with an especially large convective rain event in northern Vermont from May 26 to 28. The rainfall at Burlington, Vt., set records, making 2011 the wettest meteorological spring (March-May) on record at 19.94 in. (Vermont State Climate Office, 2011a, b).

Tropical Storm Irene resulted in widespread, intense rainfall on August 28 and 29. Across Vermont, observed rainfall ranged from 3.2 to 8.15 in., setting daily rainfall records at several rain gages (Vermont State Climate Office, 2011c). Rainfall totals across most of New Hampshire ranged from a little less than 3 in. to almost 6 in. (National Weather Service, 2011). The Northeast Regional Climate Center (2011a) reported a rainfall total of more than $10 \mathrm{in.}$ in the White Mountains of New Hampshire. In western Massachusetts, observed rainfall from Tropical Storm Irene ranged from $3 \mathrm{in}$. to a maximum of $9.92 \mathrm{in}$. (National Weather Service, 2011).

In 2011, Vermont, New Hampshire, and eastern New York experienced the wettest August since record keeping began in 1895. Massachusetts experienced its second wettest August (Northeast Regional Climate Center, 2011a, b).

\section{Peak Discharge and Lake Elevation Data for Water Year 2011}

Water year 2011 peak discharge and lake elevation data for the 145 gages included in this study (fig. 1) are compiled in appendix 2. Data for USGS gages in operation during the 2011 water year are also published in the USGS waterresources data report for the 2011 water year (U.S. Geological Survey, 2012a). Peak discharge data for streamgage 01145000 Mascoma River at West Canaan, N.H., were provided by the New Hampshire Department of Environmental Services.

At USGS streamgages not in operation during the 2011 water year, peak discharges were determined by indirect methods (these sites are identified in appendix 2 with footnote "a") or by extending the most recent stage-discharge relation to the observed stage (these sites are identified in appendix 2 with footnote "c"). In determining a peak discharge by indirect methods, high-water marks upstream and downstream from a bridge or culvert are surveyed and used to adjust a hydraulic model of the bridge or culvert. The models, with results conforming to the observed high-water marks, provide the estimated discharge (Bodhaine, 1968; Matthai, 1967; and Hulsing, 1967). 


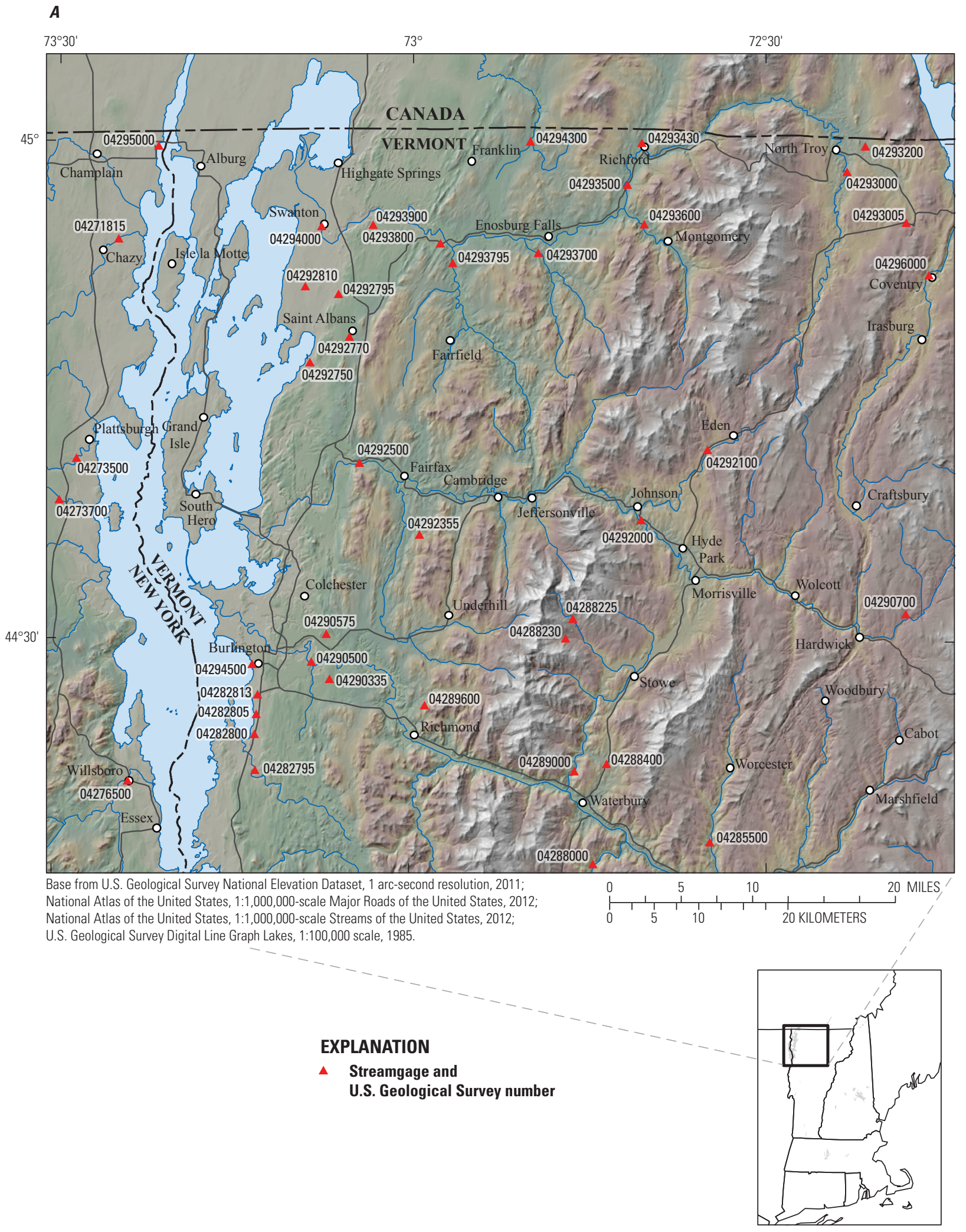

Figure 1. Location of streamgages and lake gages that have data for the 2011 water year, in $A$, northwest section, $B$, northeast section, $C$, western section, $D$, eastern section, and $E$, southern section of Vermont, and $F$, western Massachusetts section. 


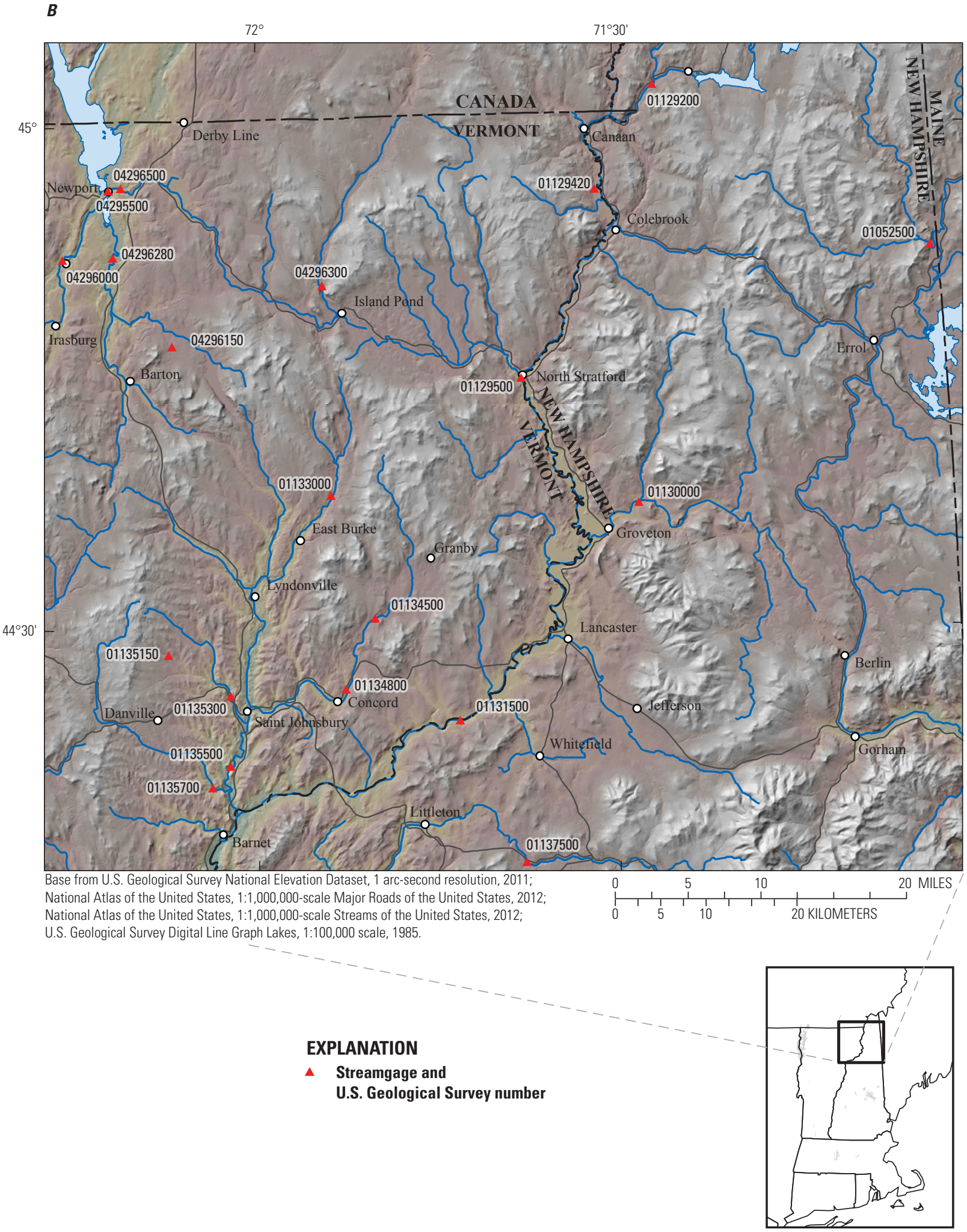

Figure 1. Location of streamgages and lake gages that have data for the 2011 water year, in $A$, northwest section, $B$, northeast section, $C$, western section, $D$, eastern section, and $E$, southern section of Vermont, and $F$, western Massachusetts section.-Continued 
c

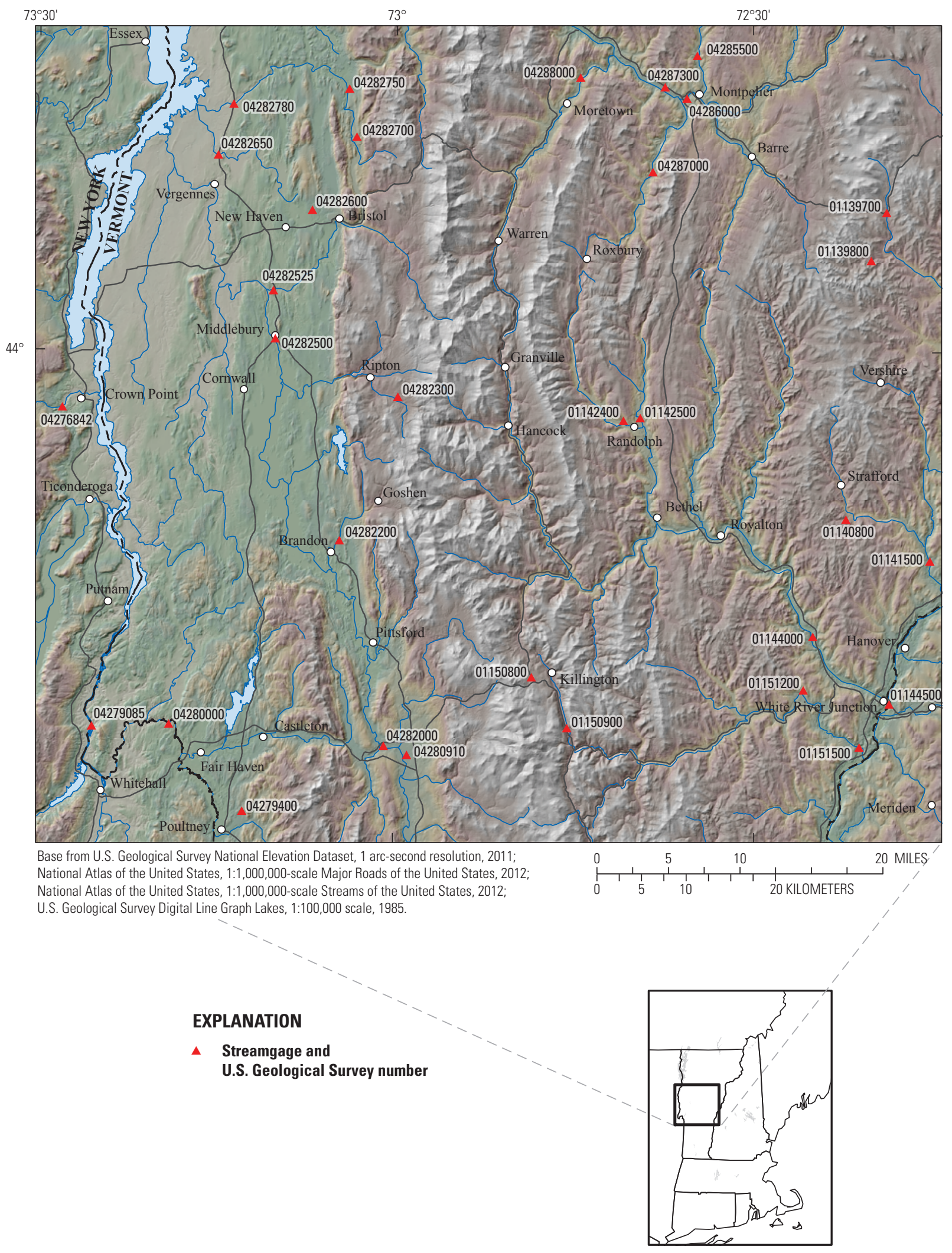

Figure 1. Location of streamgages and lake gages that have data for the 2011 water year, in $A$, northwest section, $B$, northeast section, $C$, western section, $D$, eastern section, and $E$, southern section of Vermont, and $F$, western Massachusetts section.-Continued 
D

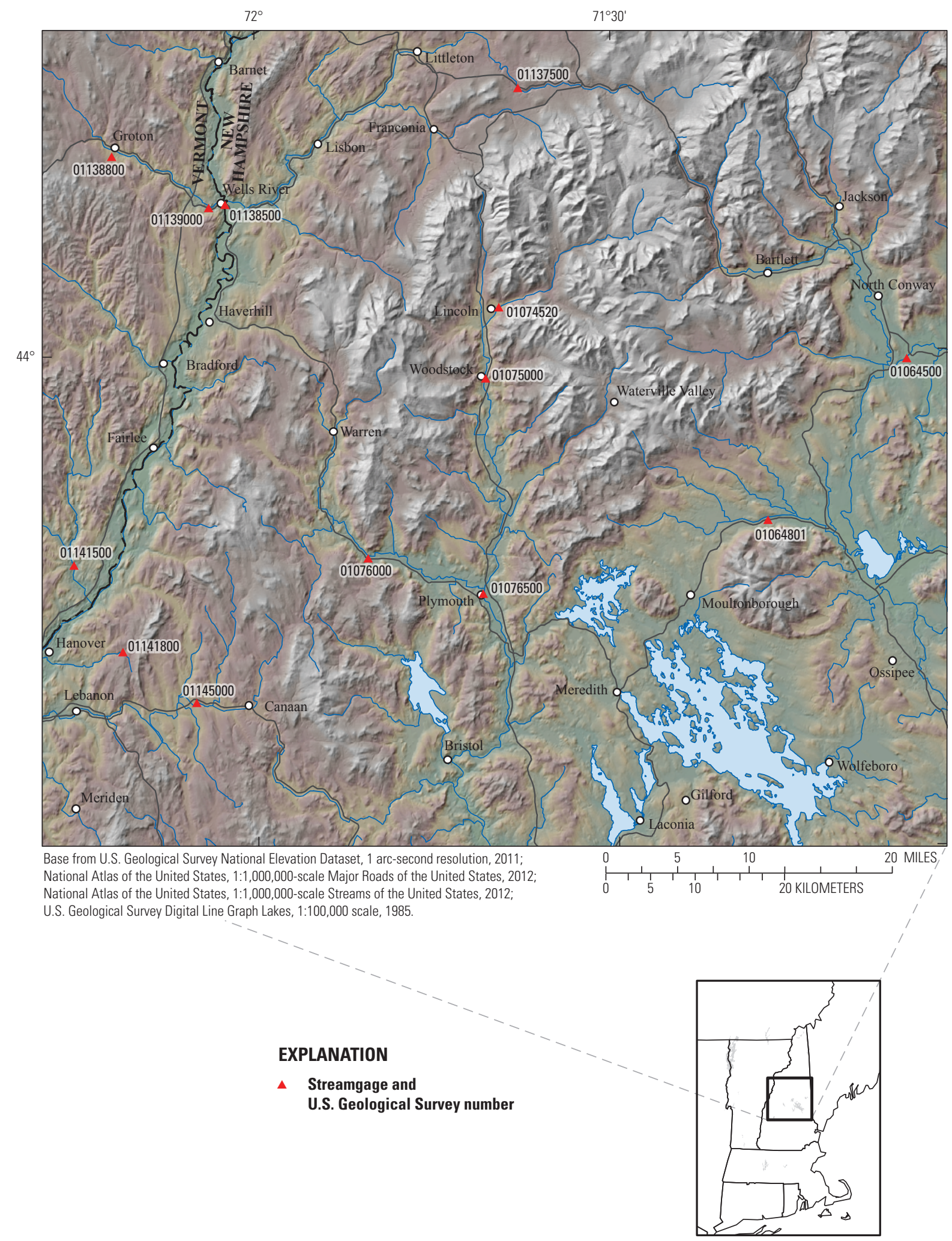

Figure 1. Location of streamgages and lake gages that have data for the 2011 water year, in $A$, northwest section, $B$, northeast section, $C$, western section, $D$, eastern section, and $E$, southern section of Vermont, and $F$, western Massachusetts section.-Continued 


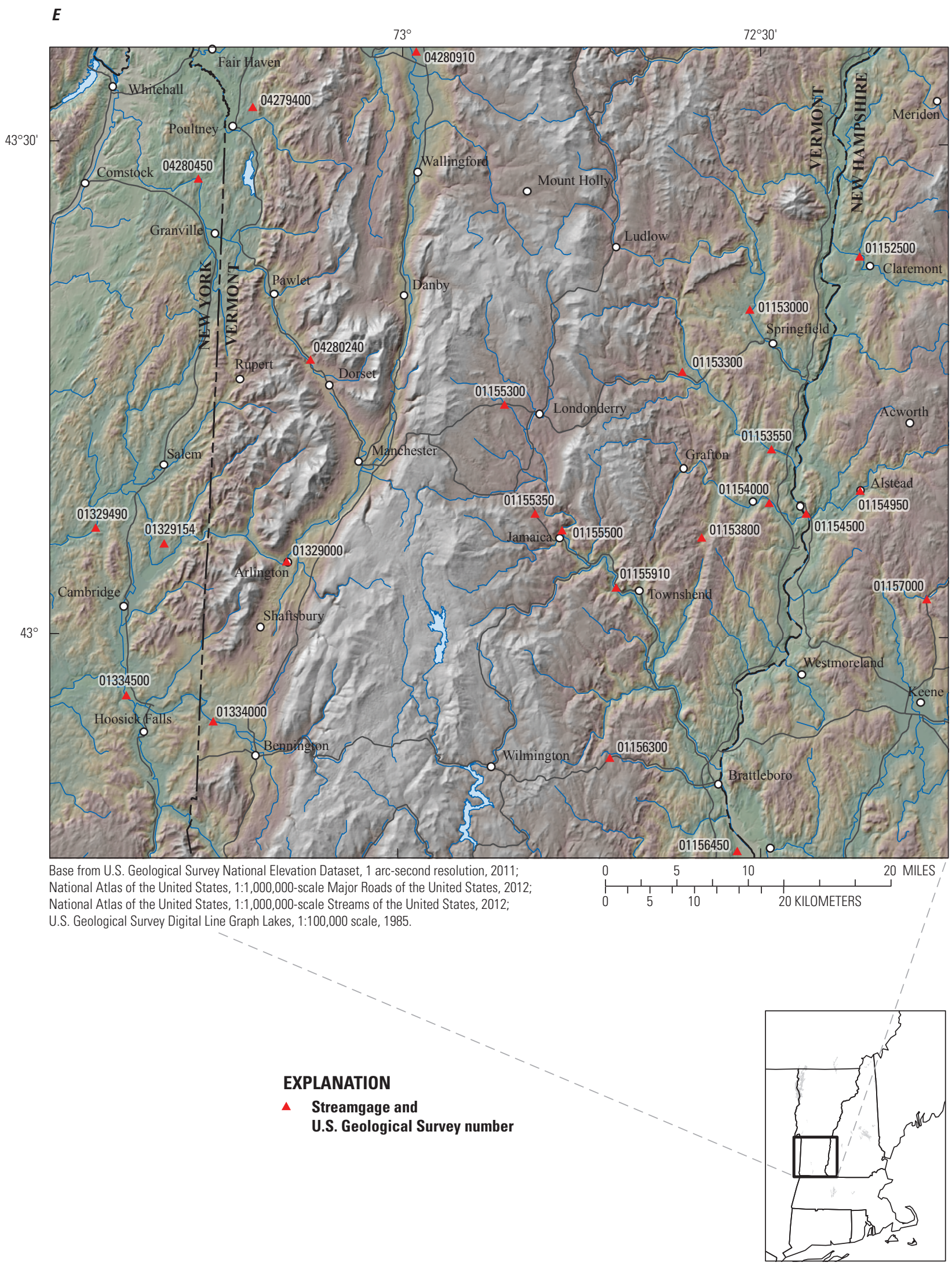

Figure 1. Location of streamgages and lake gages that have data for the 2011 water year, in $A$, northwest section, $B$, northeast section, $C$, western section, $D$, eastern section, and $E$, southern section of Vermont, and $F$, western Massachusetts section. -Continued 
$\boldsymbol{F}$

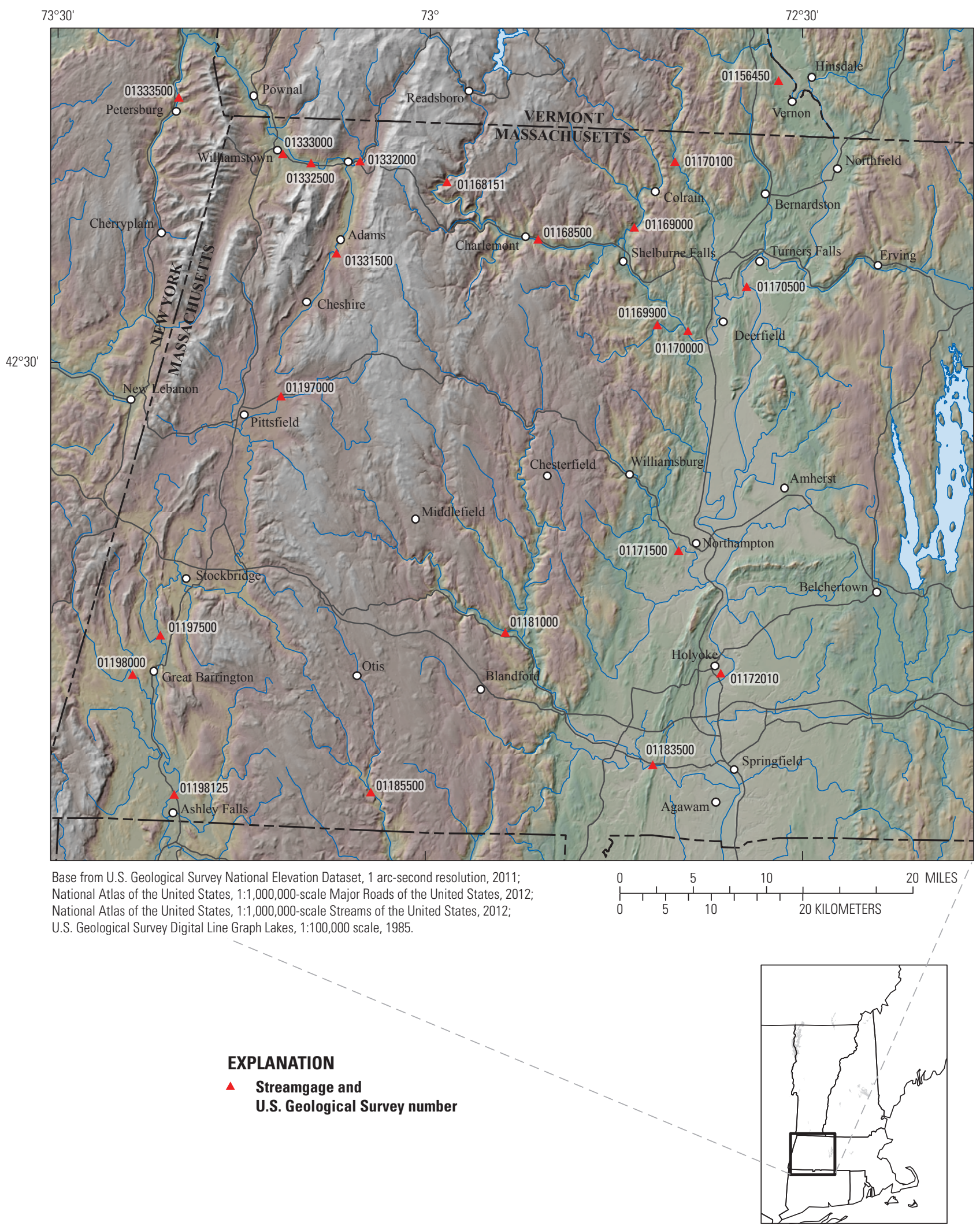

Figure 1. Location of streamgages and lake gages that have data for the 2011 water year, in $A$, northwest section, $B$, northeast section, $C$, western section, $D$, eastern section, and $E$, southern section of Vermont, and $F$, western Massachusetts section. 


\section{Frequency Analyses}

Of the 145 streamgages with peak discharges reported for the 2011 water year in this investigation, 25 streamgages did not have the minimum requirement of 10 years of peak discharge data for a frequency analysis. The annual exceedance probabilities (AEP) for 15 of these 25 streamgages were estimated by using regression equations (Olson, 2002). The remaining 10 of the 25 streamgages had basin characteristics or substantial streamflow regulation that made the regression equations inapplicable. No frequency characteristics are reported for these 10 streamgages.

For 120 of the 145 streamgages having at least 10 years of peak discharge data, the Expected Moments Algorithm (EMA) (Cohn and others, 1997 and 2001) was used for the frequency analysis. The EMA methodology generally follows guidelines provided in Bulletin 17B of the U.S. Interagency Advisory Committee on Water Data (1982) and guidelines from the U.S. Geological Survey (2012b). EMA uses the logPearson Type III distribution for estimating flow frequency; however, it provides updated procedures for incorporating historical peaks and censored peaks, and detecting and treating outliers. Software developed by the USGS to analyze peak-discharge data (PeakFQ version 7.0) was used for these computations (U.S. Geological Survey, 2013a). The peak-

flow data used as input to the PeakFQ program were retrieved from the National Water Information System (U.S. Geological Survey, 2013b). Peak discharges for 2011 were included in the frequency analysis.

If peak discharges at a streamgage were affected by substantial regulation, defined by Benson and Dalrymple (1967) as regulation having usable storage greater than 4.5 million cubic feet per square mile of drainage area, the station skew was used for the discharge frequency analysis. Frequency analysis was done only on the period of record associated with the current regulation conditions upstream from each gage.

At streamgage sites without regulation affecting the peak discharge, the station skew was weighted with a generalized skew according to methods described in Bulletin 17B. Generalized skew was derived from Olson's (2002) skew map covering streamgages in Vermont and adjacent states that were used in developing the map. The generalized skew map in Bulletin 17B was used for weighting station skew for unregulated streamgages in Massachusetts outside of the areas used to develop the Vermont generalized skew map. A generalized skew map developed for New Hampshire (Olson, 2009) was used for weighting station skew for unregulated streamgages in New Hampshire outside of the areas used to develop the Vermont generalized skew map.

For streamgages with unregulated peak discharges, the EMA discharge frequencies were weighted by use of the Weighted Independent Estimates (WIE) (Cohn and others, 2012) method. WIE uses the variance of the frequency estimate from the EMA analysis and the variance of an available regional-regression equation estimate to weight the EMA result. The regional-regression equations in Olson (2002) were used for streamgages in Vermont and adjacent states that were used in the report. The regression equations for New Hampshire (Olson, 2009) were used for streamgages in New Hampshire that were outside of the area used for developing the Vermont regression equations. Unregulated streamgages in Massachusetts that were outside of the area used in developing the Vermont regression equation do not have an associated regional-regression equation and therefore were not weighted. Both the EMA and the weighted EMA results are listed in appendix 3.

The annual exceedance probability of the 2011 peak discharge is shown for each streamgage in appendix 2. During the 2011 water year, 50 streamgages or lake gages recorded a peak with an annual exceedance probability less than or equal to 1 percent (100-year recurrence interval); 18 of these had an annual exceedance probability less than or equal to 0.2 percent (500-year recurrence interval) (fig. 2). Of these 50 gages, one (Moose River at Victory, Vt.) had a peak discharge during a hydrologic event not discussed in this report.

\section{Lake Champlain Peak Elevations and Frequency Analyses}

Lake elevations of Lake Champlain from May 6-9, 2011, were the highest ever recorded-102.79 ft of the North American Vertical Datum of 1988 (NAVD 88) at the Burlington, Vt., gage; $102.75 \mathrm{ft}$ NAVD 88 at the Rouses Point, N.Y., gage; and $103.06 \mathrm{ft}$ NAVD 88 at the Whitehall, N.Y., gage. Both the Burlington, Vt., and the Rouses Point, N.Y., gages have over 100 years of record; records for the Rouses point gage extend back to 1869 - the year of the second highest recorded lake elevation of $102.10 \mathrm{ft}$ NAVD 88.

The historical range of the logarithms of Lake Champlain elevation data is too small to provide meaningful frequency results. For instance, at the Burlington gage the highest annual peak elevation is $102.79 \mathrm{ft}$, and the lowest annual peak elevation is $95.20 \mathrm{ft}$ NAVD 88. The range for these values and their logarithms is too small to generate reliable frequencies. Therefore, a relation was developed between lake watersurface elevation and the volume of water in the lake with the intent of deriving frequency statistics from annual maximum lake volume and converting the results back to elevation. The relation was derived from a 10 -meter digital elevation model (Gesch and others, 2009) of land terrain around Lake Champlain merged with the 10-meter bathymetry dataset (Manley and others, 2005). A geographic information system (GIS) was used to compute the lake volume for water-surface elevations between 95.00 and $103.75 \mathrm{ft}$ above the NAVD 88 .

Three gages have annual peak elevation data for the lake: 04279085 Lake Champlain North of Whitehall, N.Y. (fig. 1C); 04294500 Lake Champlain at Burlington, Vt. (fig. 1A); and 04295000 Richelieu River (Lake Champlain) at Rouses Point, N.Y. (fig. 1A). A fourth gage, Lake Champlain at Philipsburg, Quebec, operated by Environment Canada from 1950 to 2011 
A

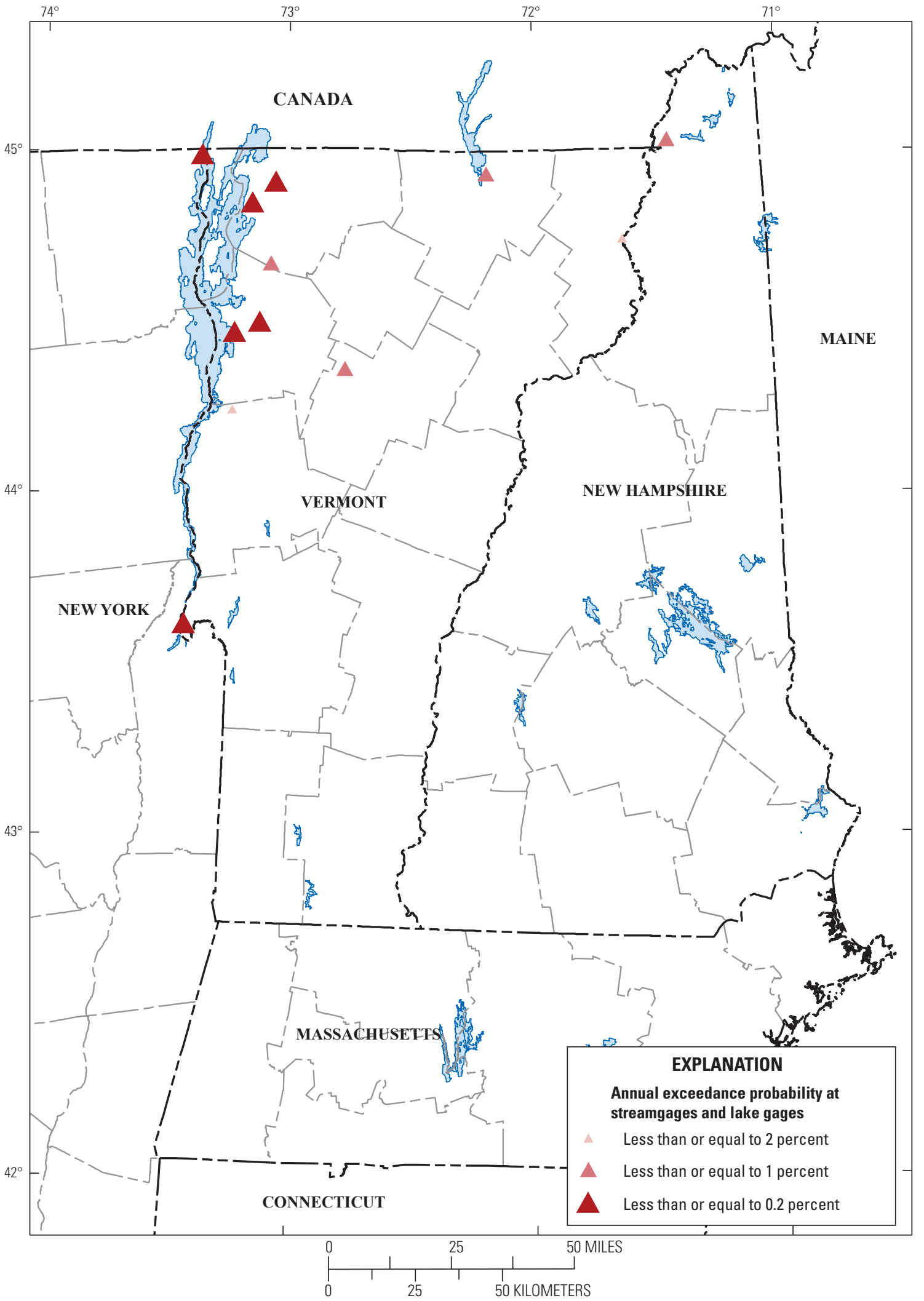

Figure 2. Annual exceedance probabilities less than or equal to 2 percent at streamgages with annual peak discharges during the A, April 2011 rain event or Lake Champlain flooding; B, May 2011 rain event; and C, August 2011 Tropical Storm Irene. 
B

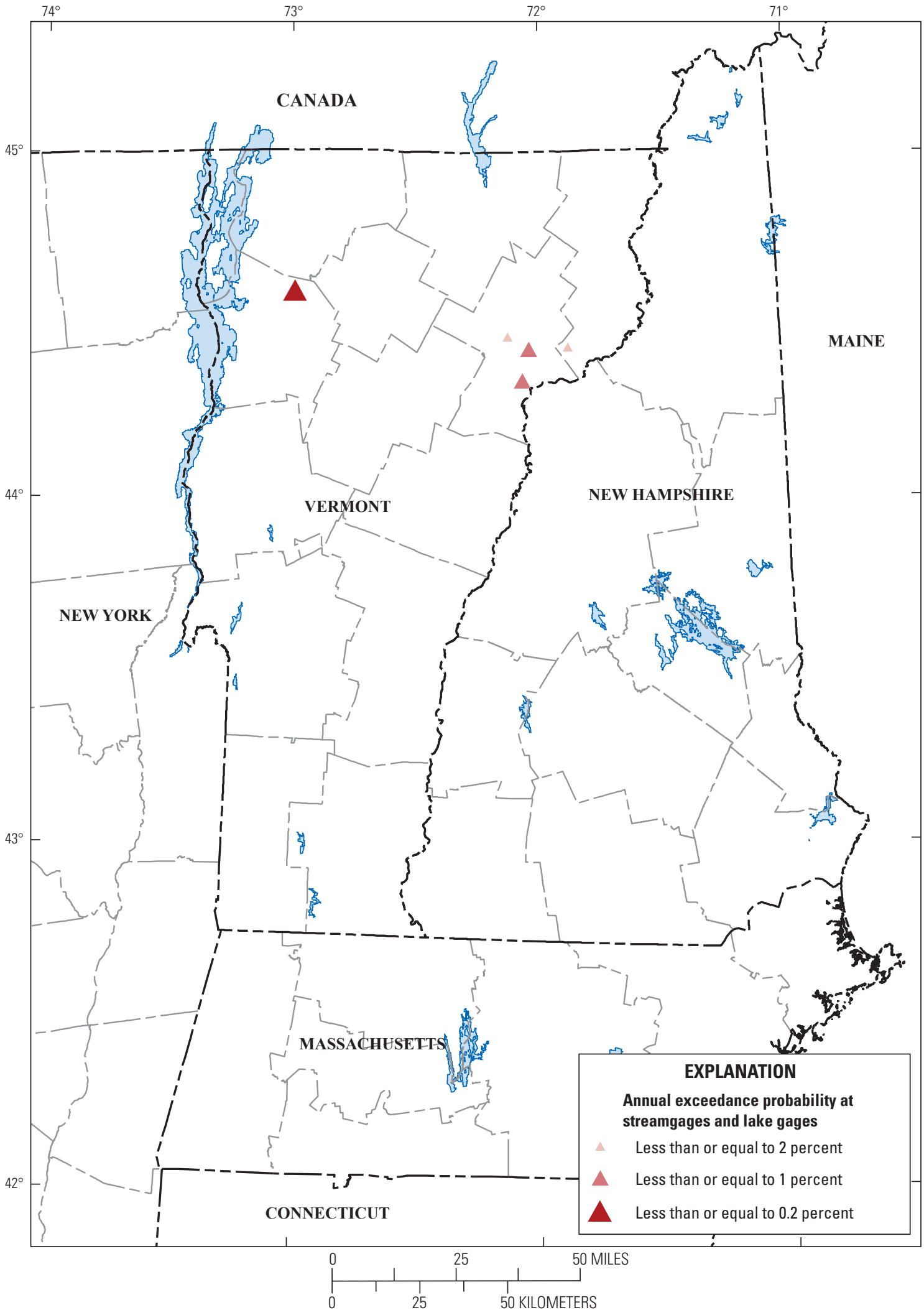

Figure 2. Annual exceedance probabilities less than or equal to 2 percent at streamgages with annual peak discharges during the A, April 2011 rain event or Lake Champlain flooding; B, May 2011 rain event; and C, August 2011 Tropical Storm Irene.-Continued 
$c$

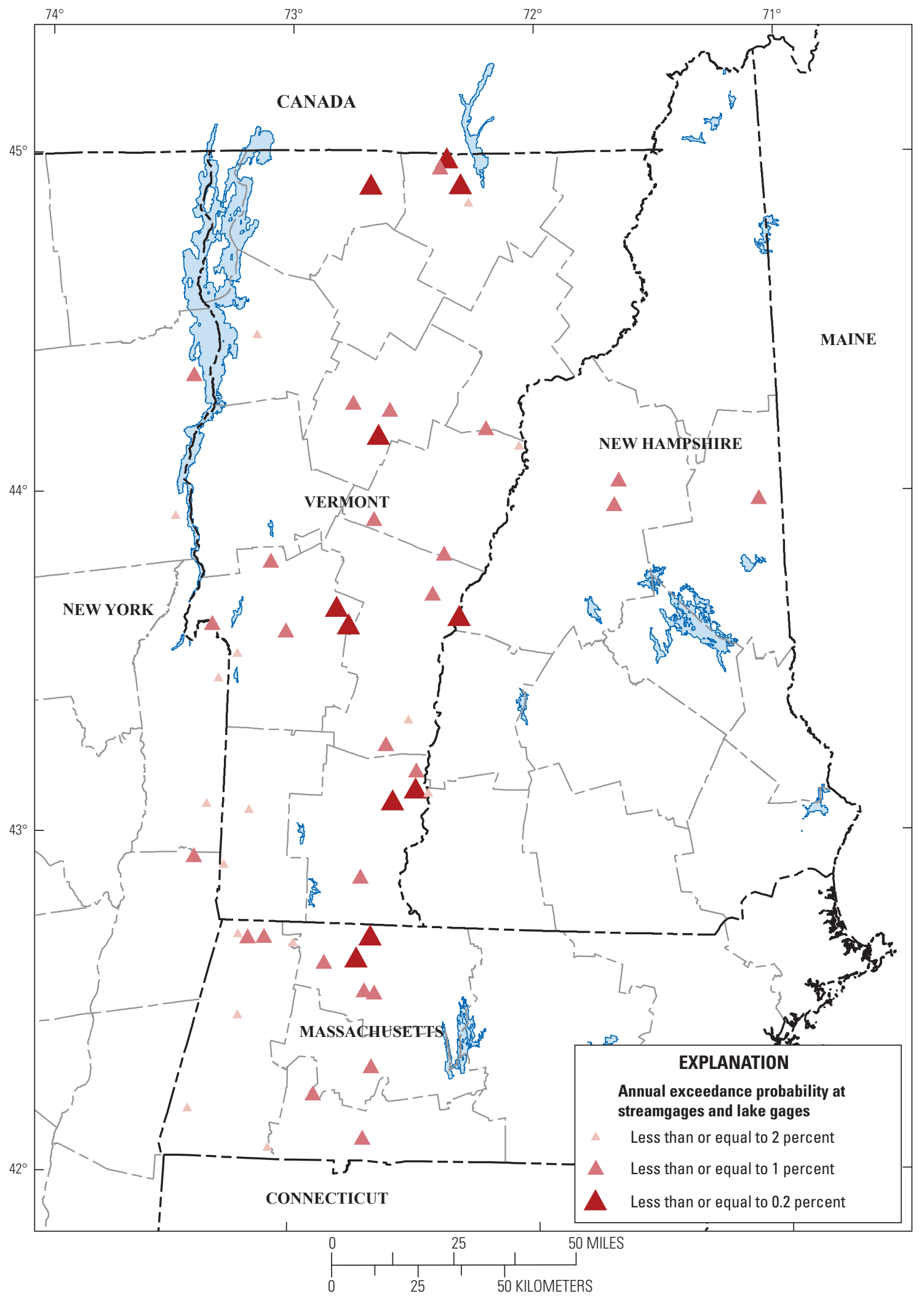

Figure 2. Annual exceedance probabilities less than or equal to 2 percent at streamgages with annual peak discharges during the A, April 2011 rain event or Lake Champlain flooding; B, May 2011 rain event; and C, August 2011 Tropical Storm Irene.-Continued 
was not used because of difficulties rectifying differences between the USGS and Environment Canada datums. Prior to 1940, annual peak lake elevation at the Burlington, Vt., and Rouses Point, N.Y., gages were based on once daily or once every third day observations. Because the annual peak could be missed by this frequency of observation, particularly if seiche is a contributing factor, the systematic record for EMA analysis at these sites was limited to the period 1940 to 2011. A peak elevation from 1869 at the Rouses Point gage was used in the analysis as a historic peak at each of the gages.

The published peak elevation data from the lake gages were converted from National Geodetic Vertical Datum of 1929 to NAVD 88 by using the National Geodetic Survey online VERTCON tool (http://www.ngs.noaa.gov/cgi-bin/ VERTCON/vert_con.prl). The converted peak elevation at each station was then used with the elevation-volume relation to determine the annual peak volume for each gage. A frequency analysis using EMA was then completed on the annual lake volumes. An additional frequency analysis was done on the three-gage average annual peak volumes for comparison. The results of the frequency analysis were converted from volume back to elevation in NAVD 88 and are listed in table 1 .

The annual exceedance probability of the 2011 water year peak lake elevation was less than or equal to 0.2 percent at all three lake gages. However, sieche and the effects of wind on the peak water-surface elevation could vary substantially along shoreline areas away from the gages. Also, the period of record of the Lake Champlain North of Whitehall, N.Y., gage is 1999 to 2011, which is substantially less than the records for the other Lake Champlain gages. The frequencies developed in this investigation are pertinent to the gage locations and are intended to describe the frequency of the flooding in 2011.

Table 1. Elevations of Lake Champlain, Vermont and New York, for selected annual exceedance probabilities.

[USGS, U.S. Geological Survey; ft, feet; NAVD 88, North American Vertical Datum of 1988; \%, percent; N.Y., New York; Vt., Vermont; --, not applicable]

\begin{tabular}{clrrrrr}
\hline \multirow{2}{*}{$\begin{array}{c}\text { USGS } \\
\text { streamgage } \\
\text { number }\end{array}$} & \multicolumn{1}{c}{ Station name } & \multicolumn{5}{c}{ Lake elevation for given annual exceedance probability, } \\
ft, NAVD 88
\end{tabular}

\section{Summary}

Vermont, New Hampshire, western Massachusetts, and northeastern New York experienced several record breaking hydrologic events during the 2011 water year. Snowmelt and near record rainfall led to flooding across northern Vermont on April 27 and 28, 2011. In early May 2011, new peak stage records were set at three Lake Champlain gages. Recordbreaking rainfall in late May resulted in additional flooding across northern Vermont on May 26 and 27, 2011. In addition, from August 28 to 29, 2011, Tropical Storm Irene delivered rainfall totals of about 3 to 10 inches, which resulted in extensive flooding across the entire study area.

Of the 145 streamgages and lake gages examined, 47 with more than 10 years of record had a new peak of record during the events of 2011. Of these 47 peaks of record, 3 occurred as a result of the April 27-28, 2011, event; 3 occurred as a result of the flooding of Lake Champlain in early May; 4 occurred as a result of the May 26-27, 2011, event; and 37 occurred as a result of Tropical Storm Irene, August 28 and 29, 2011.
During the 2011 water year, peak discharges at 32 streamgages had an annual exceedance probability less than or equal to 1 percent but greater than 0.2 percent (equal to or greater than a 100-year recurrence interval but less than a 500 -year recurrence interval). Of these 32 peak discharges, 5 were due to the April event, 2 were due to the late May event, and 25 were due to Tropical Storm Irene. Peak discharges at 15 streamgages had an annual exceedance probability less than or equal to 0.2 percent (equal to or greater than a 500 year recurrence interval). Of these 15 peak discharges, 3 were due to the April event, 1 was due to the late May event, and 11 were due to Tropical Storm Irene in August.

Lake elevations of Lake Champlain from May 6-9, 2011, were the highest ever recorded-102.79 $\mathrm{ft}$ NAVD 88 at the Burlington, Vt., gage; $102.75 \mathrm{ft}$ NAVD 88 at the Rouses Point, N.Y., gage; and $103.06 \mathrm{ft}$ NAVD 88 at the Whitehall, N.Y., gage. The Burlington, Vt., and the Rouses Point, N.Y., gages have over 100 years of record, with the Rouses Point gage record extending back to 1869 - the year of the second highest recorded lake elevation of $102.10 \mathrm{ft}$ NAVD 88 . The annual exceedance probability of the lake elevation was less than or equal to 0.2 percent (equal or greater than a 500 -year recurrence interval) at each of three lake gages. 


\section{Selected References}

Benson, M.A., and Dalrymple, Tate, 1967, General field and office procedures for indirect discharge measurements: U.S. Geological Survey Techniques of Water-Resources Investigations, book 3, chap. A1, $30 \mathrm{p}$.

Bodhaine, G.L., 1968, Measurement of peak discharge at culverts by indirect methods: U.S. Geological Survey Techniques of Water-Resources Investigations, book 3, chap. A3, $60 \mathrm{p}$.

Cohn, T.A., Berenbrock, Charles, Kiang, J.E., and Mason, R.R., Jr., 2012, Calculating weighted estimates of peak streamflow statistics: U.S. Geological Survey Fact Sheet 2012-3038, 4 p. (Also available at http://pubs.usgs.gov/ fs $/ 2012 / 3038 /$.

Cohn, T.A., Lane, W.M., and Baier, W.G., 1997, An algorithm for computing moments-based flood quantile estimates when historical flood information is available: Water Resources Research, v. 33, no. 9, p. 2089-2096.

Cohn, T.A., Lane, W.M., and Stedinger, J.R., 2001, Confidence intervals for expected moments algorithm flood quantile estimates: Water Resources Research, v. 37, no. 6, p. $1695-1706$.

Flynn, K.M., Kirby, W.H., and Hummel, P.R., 2006, User's manual for PeakFQ, annual flood frequency analysis using bulletin 17B guidelines: U.S. Geological Survey Techniques and Methods Report, book 4, chap. B4, 42 p.

Gesch, D., Evans, G., Mauck, J., Hutchinson, J., and Carswell, W.J., Jr., 2009, The National map — elevation: U.S. Geological Survey Fact Sheet 2009-3053, 4 p.

Hulsing, H., 1967, Measurement of peak discharge at dams by indirect methods: U.S. Geological Survey Techniques of Water-Resources Investigations, book 3, chap. A5, 29 p.

Manley, T.O., Manley, P.L., and Fisher, G.B., 2005, Bathymetry of Lake Champlain, copyrighted bathymetric map and digital database: Middlebury, Vt., Middlebury College.

Matthai, H.F., 1967, Measurement of peak discharge at width contractions by indirect methods: U.S. Geological Survey Techniques of Water-Resources Investigations, book 3, chap. A4, 44 p.

National Weather Service, 2011, Public information statement, Spotter reports: Taunton, Mass., August 30, 2011, accessed February 12, 2013, at http://www.erh.noaa.gov/box/ displayEvent.php?event=Aug_27-28_2011\&element=pcpn.

National Weather Service, 2012, Climatalogical report (Annual): Pittsfield, Mass., accessed April 3, 2013, at http://forecast.weather.gov/product.php?site=NWS\&product $=$ CLA\&issuedby $=$ PSF.
National Weather Service, 2013, Vermont Climatology, accessed April 3, 2013, at http://www.erh.noaa.gov/btv/ climo/stations/.

Northeast Regional Climate Center, 2011a, New England Climate-August 2011, v. 111, no. 8, 29 p., accessed April 8, 2013, at http://www.nrcc.cornell.edu/pubs/msmry_ne_201108.pdf.

Northeast Regional Climate Center, 2011b, New York Climate-August 2011, v. 111, no. 8, 13 p., accessed April 8, 2013, at http://www.nrcc.cornell.edu/pubs/msmry_ny_201108.pdf.

Olson, S.A., 2002, Flow-frequency characteristics of Vermont streams: U.S. Geological Survey Water-Resources Investigations Report 02-4238, $47 \mathrm{p}$.

Olson, S.A., 2009, Estimation of flood discharges at selected recurrence intervals for streams in New Hampshire: U.S. Geological Survey Scientific Investigations Report 20085206, $57 \mathrm{p}$.

U.S. Geological Survey, 2012a, Water-resources data for the United States, water year 2011: U.S. Geological Survey Water-Data Report WDR-US-2011, accessed August 20, 2013, at http://wdr.water.data.gov.

U.S. Geological Survey, 2012b, Computation of annual exceedance probability (AEP) for characterization of observed flood peaks: U.S. Geological Survey Office of Surface Water Technical Memorandum 2013.01, 7 p., accessed April 8, 2013, at http://water.usgs.gov/admin/ memo/SW/sw13.01.pdf.

U.S. Geological Survey, 2013a, Water resources application software, PeakFQ, accessed April 3, 2013, at http://water. usgs.gov/software/peakfq.html.

U.S. Geological Survey, 2013b, Peak streamflow for the Nation: National Water Information System, accessed April 3, 2013, at http://nwis.waterdata.usgs.gov/usa/nwis/ peak.

U.S. Interagency Advisory Committee on Water Data, 1982, Guidelines for determining flood flow frequency, Bulletin 17-B of the Hydrology Subcommittee: Reston, Va., U.S. Geological Survey, Office of Water Data Coordination, $183 \mathrm{p}$.

Vermont State Climate Office, 2011a, Climate impacts summary, April 2011, accessed February 12, 2013, at http://www.uvm.edu/ vtstclim/?Page=climate_impacts. html.

Vermont State Climate Office, 2011b, Climate impacts summary, May 2011, accessed February12, 2013, at http://www.uvm.edu/ vtstclim/?Page=climate_impacts. html. 
Vermont State Climate Office, 2011c, Climate impacts summary, August 2011, accessed February 12, 2013, at http://www.uvm.edu/ vtstclim/?Page=climate_impacts. html.

Vermont State Climate Office, 2013, Vermont climate, accessed February 12, 2013, at http://www. uvm.edu/ vtstclim/?Page=climate_vermont. html\&SM=vtclimsub.html. 
THIS PAGE INTENTIONALLY LEFT BLANK 
Appendix 1. Location Descriptions of Streamgages and Lake Gages Used to Characterize 2011 Flooding in Vermont, Northern New Hampshire, Western Massachusetts, and Northeastern New York

[Available separately at http://pubs.usgs.gov/sir/2013/5187/]

\begin{abstract}
Appendix 2. Peak Discharge or Stage Occurring in 2011 at Streamgages or Lake Gages Used to Characterize 2011 Flooding in Vermont, Northern New Hampshire, Western Massachusetts, and Northeastern New York
\end{abstract}

[Available separately at http://pubs.usgs.gov/sir/2013/5187/]

Appendix 3. Discharges for Selected Annual Exceedance Probabilities at Streamgages Used to Characterize Flooding in 2011 in Vermont, Northern New Hampshire, Western Massachusetts, and Northeastern New York

[Available separately at http://pubs.usgs.gov/sir/2013/5187/] 
Prepared by the Pembroke and West Trenton Publishing Service Centers.

For more information concerning this report, contact:

Office Chief

U.S. Geological Survey

New England Water Science Center

New Hampshire-Vermont Office

331 Commerce Way, Suite 2

Pembroke, NH 03275

dc_nh@usgs.gov

or visit our Web site at:

http://nh.water.usgs.gov 


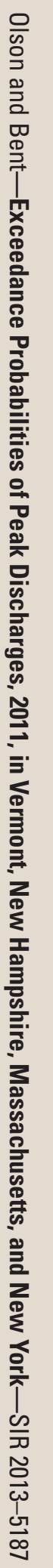

